\title{
RAT HEPATOCYTE INVASION BY Listeria monocytogenes AND ANALYSIS OF TNF- $\alpha$ ROLE IN APOPTOSIS
}

\author{
Sânia Alves dos SANTOS, Dahir Ramos de ANDRADE \& Dahir Ramos de ANDRADE JÚNIOR
}

\begin{abstract}
SUMMARY
Listeria monocytogenes, etiological agent of severe human foodborne infection, uses sophisticated mechanisms of entry into host cytoplasm and manipulation of the cellular cytoskeleton, resulting in cell death. The host cells and bacteria interaction may result in cytokine production as Tumor Necrosis Factor (TNF) $\alpha$. Hepatocytes have potential to produce pro-inflammatory cytokines as TNF- $\alpha$ when invaded by bacteria. In the present work we showed the behavior of hepatocytes invaded by L. monocytogenes by microscopic analysis, determination of TNF- $\alpha$ production by bioassay and analysis of the apoptosis through TUNEL technique. The presence of bacterium, in ratios that ranged from 5 to 50,000 bacteria per cell, induced the rupture of cellular monolayers. We observed the presence of internalized bacteria in the first hour of incubation by electronic microscopy. The levels of TNF- $\alpha$ increased from first hour of incubation to sixth hour, ranging from 0 to $3749 \mathrm{pg} / \mathrm{mL}$. After seven and eight hours of incubation nonsignificant TNF- $\alpha$ levels decrease occurred, indicating possible saturation of cellular receptors. Thus, the quantity of TNF- $\alpha$ produced by hepatocytes was dependent of the incubation time, as well as of the proportion between bacteria and cells. The apoptosis rate increased in direct form with the incubation time $(1 \mathrm{~h} \mathrm{to} 8+24 \mathrm{~h})$, ranging from 0 to $43 \%$, as well as with the bacteria : cells ratio. These results show the ability of hepatocyte invasion by non-hemolytic L. monocytogenes, and the main consequences of this phenomenon were the release of TNF- $\alpha$ by hepatocytes and the induction of apoptosis. We speculate that hepatocytes use apoptosis induced by TNF- $\alpha$ for release bacteria to extracellular medium. This phenomenon may facilitate the bacteria destruction by the immune system.
\end{abstract}

KEYWORDS: Listeria monocytogenes; Hepatocytes; Tumor Necrosis Factor; Apoptosis.

\section{INTRODUCTION}

Listeria monocytogenes (L. monocytogenes) is a non-sporulating, Gram-positive rod that grows on blood agar and produces incomplete $\beta$ hemolysis. This microorganism is ubiquitous in soil and water and can be found in the gastrointestinal tracts of animals and up to $5 \%$ of healthy human adults ${ }^{15}$. L. monocytogenes is a food-borne pathogen responsible for listeriosis, which can lead to meningitis, meningo-encephalitis, septicemia, abortion and, in some cases, gastroenteritis. Listeriosis can appear in otherwise healthy individuals, and a more severe form of the disease is seen in immunocompromised patients. The overall mortality rate is $20 \%{ }^{15}$, and the severity of the clinical symptoms manifested is due to the unique ability of this organism to cross the intestinal barrier, the blood-brain barrier, and the placental barrier, reaching important organs like spleen and liver. This bacterium is a facultative intracellular pathogen that induces its own uptake into nonphagocytic cells and spreads from cell to cell using an actin-based motility process.

L. monocytogenes survives and replicates in macrophages. In all cell types, L. monocytogenes internalization is rapidly followed by phagocytic vacuole's lysis and bacteria release into the cytosol. In this compartment, bacteria replication occurs followed by bacteria movement to the plasma membrane, where they induce the formation of pseudopodia (also called 'listeriopods'). This structure allows bacteria invagination to the neighboring cell ${ }^{11}$. Thus, these bacteria disseminate within host cells by direct cell-to-cell transmission.

Early after infection with L. monocytogenes, macrophages secrete TNF- $\alpha$ and IL-12 that synergize in the activation of NK cells to secrete IFN- $\gamma$. IFN- $\gamma$ in conjunction with TNF- $\alpha$ leads to strong macrophage activation, resulting in a listeriocidal state of macrophages ${ }^{27}$. The macrophages also synthesize nitric oxide (NO) by induction of inducible nitric oxide synthase (iNOS), and the NO can neutralize bacteria as $L$. monocytogenes ${ }^{20}$.

Interaction between $L$. monocytogenes and host cells may result in the release of one or more cytokines. TNF- $\alpha$ is an important cytokine with varied biological functions, and its mechanism of action is complex. This protein carries out opposing roles, conferring resistance to certain types of infections on the one hand and causing pathological

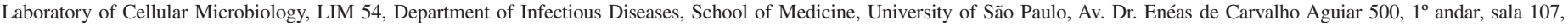
05403-000 São Paulo, SP, Brazil.

Correspondence to: Sânia Alves dos Santos, Rua Duarte de Azevedo 223, apto. 60, 02036-020, São Paulo, SP, Brazil. Phone 5511-6971-2659, e-mail: saniasan@usp.br 
complications on the other ${ }^{10}$. This cytokine may contribute to infection resistance through activation of neutrophils and platelets, enhancement of macrophage/NK cell-killing abilities, and stimulation of the immune system $^{10}$. It has been also shown that TNF- $\alpha$ may induce, in vitro and in vivo, apoptotic cell death in rat hepatocytes ${ }^{21}$.

The TNF- $\alpha$ receptor super-family consists of several members sharing a sequence homology in a unique function domain, the death domain, which is located in the intracellular portion of the receptor. These socalled death receptors, including Fas, TNF-R1 and TRAIL-R1/ TRAIL-R2, are expressed on hepatocytes. When stimulated by their ligands, FasL, TNF- $\alpha$ or TRAIL, respectively, the death receptors can activate multiple death domain-initiated apoptosis programs, including both extrinsic and intrinsic pathways. A cascade of caspases is activated, which cleave important proteins for the cell structure and function. Activation of the intrinsic pathway also leads to mitochondrial release of several apoptotic proteins and mitochondrial dysfunction, which kill the cell through both caspase-dependent and caspase-independent mechanisms. Apoptosis induced by death receptors contribute to the development of several liver diseases, including viral hepatitis, inflammatory hepatitis, Wilson's disease, alcoholic liver disease, endotoxiemia-induced liver failure and ischemia/ reperfusion-induced liver damage ${ }^{30,31}$.

In the present work we studied the behavior of hepatocytes invaded by L. monocytogenes through microscopic analysis, determination of TNF- $\alpha$ production by bioassay and analysis of the apoptosis by TUNEL technique. We showed that hepatocytes invaded by L. monocytogenes produce TNF- $\alpha$ in a time-progressive pattern. The hepatocytes apoptosis rate increased in a time-dependent form as well as with the bacteria: hepatocytes ratio.

The study of cellular invasion, employing specific pathogenic microorganisms, may elucidate its manner of action inside the cells, and this will contribute to develop sophisticated methodologies to take care of patients with serious infectious processes.

\section{METHODS}

1) Primary rat hepatocytes culture: Hepatocytes of newborn Wistar rats (approximately 15 female rats per assay) were cultured in a primary culture model using a collagenase method with modifications $^{2}$. Isolated hepatocytes were seeded into laminin (Sigma)-coated culture T-25 flasks (Corning) and cultured for five days before experimental assay. Immunohistochemical testing, lactate dehydrogenase $(\mathrm{LDH})$ isoenzyme and albumin dosage in the supernatants were made to confirm hepatocytes culture.

Cells were maintained in culture at $37{ }^{\circ} \mathrm{C}$ in a humidified atmosphere of $5 \% \mathrm{CO}_{2}$ in air $^{2}$. Cells were cultured in the following: Williams E medium (Sigma) containing 2\% (v/v) fetal bovine serum (Cultilab); $10^{-8} \mathrm{M}$ insulin (Sigma); $10^{-9} \mathrm{M}$ glucagon (Sigma); $10 \mu \mathrm{U} / \mathrm{mL}$ growth hormone (Sigma); $10 \mathrm{ng} / \mathrm{mL}$ epidermal growth factor (Sigma); $100 \mu \mathrm{g} / \mathrm{mL}$ ampicillin (Sigma); $100 \mu \mathrm{g} / \mathrm{mL}$ streptomycin (Sigma); $5 \mu \mathrm{g} / \mathrm{mL}$ amphotericin (Sigma); $1 \mathrm{~g} / \mathrm{L}$ HEPES (Sigma); $1 \mathrm{~g} / \mathrm{L}$ sodium bicarbonate (Sigma) and $5 \times 10^{-8} \mathrm{M}$ hydrocortisone (Sigma).

2) Cell viability: The cell viability of hepatocytes was determined by trypan-blue exclusion method. This dye penetrates only the non- viable cells. Viable cells (unstained) and non-viable cells (stained) were counted in a Neubauer chamber.

3) Cell lines culture: The murine fibroblastic cell line L929 was obtained from The American Type Culture Collection (ATCC). The L929 cells were maintained in culture using RPMI-1640 medium (Sigma) containing 10\% (v/v) fetal bovine serum (Cultilab), $100 \mathrm{U} / \mathrm{mL}$ penicillin (Sigma), $100 \mathrm{U} / \mathrm{mL}$ streptomycin (Sigma), $2.5 \mu \mathrm{g} / \mathrm{mL}$ amphotericin (Sigma), $40 \mathrm{mg} / \mathrm{L}$ gentamicin (Sigma), $1 \mathrm{~g} / \mathrm{L}$ HEPES (Sigma) and 1g/L sodium bicarbonate (Sigma). Cells were seeded into $\mathrm{T}-25$ flasks (Corning) and cultured at $37{ }^{\circ} \mathrm{C}$ in a humidified atmosphere of $5 \% \mathrm{CO}_{2}$ in air.

4) Bacterial culture: Listeria monocytogenes strain (ATCC 19114) was grown on Brain Heart Infusion (BHI) agar (Difco) at $37{ }^{\circ} \mathrm{C}$ for 24 h. To obtain stationary phase bacteria, Tryptic Soy Broth (Difco) was inoculated with a single colony and was grown for $18-19 \mathrm{~h}$. To determine the hemolytic activity of $L$. monocytogenes, a hemolytic test was made as previously described ${ }^{9}$ and resulted negative.

5) Procedure for bacterial infection: Before each experiment, the bacteria were washed three times in phosphate-buffered saline (PBS) $\mathrm{pH} 7.4$, and adjusted to a concentration of $5 \times 10^{5}$ to $5 \times 10^{9}$ bacteria per $\mathrm{mL}$ in RPMI-1640 medium without antibiotics.

Each hepatocytes monolayer was incubated at $37^{\circ} \mathrm{C}$ with $3-4 \mathrm{~mL}$ of the bacterial suspension for 1, 2, 3, 4, 5, 6, 7, 8, and 24 h. Two-step incubations were also employed. These involved additional $24 \mathrm{~h}$ incubations $(4+24 \mathrm{~h}, 5+24 \mathrm{~h}, 6+24 \mathrm{~h}, 7+24 \mathrm{~h}$, and $8+24 \mathrm{~h})$ with gentamicin in order to remove bacteria. We named these times as composite hours.

In the two-step incubations, following the initial period of infection, the extracellular Listeria was removed by three washes with PBS. The infected monolayers were then incubated for $24 \mathrm{~h}$ in RPMI-1640 with $1 \mu \mathrm{g} / \mathrm{mL}$ gentamicin for inhibition of the extracellular L. monocytogenes multiplication ${ }^{28}$. Cells were lysed in distilled water, and the number of viable intracellular bacteria was determined by plating serial dilutions of the cell lysates on BHI agar ${ }^{23}$.

6) Detection of TNF- $\alpha$ by bioassay: The L- 929 cells were cultured in culture flasks (Corning) at $37{ }^{\circ} \mathrm{C}$ in a humidified atmosphere of $5 \%$ $\mathrm{CO}_{2}$ in air. L-929 suspensions for flat-bottom microtiter plates of 96well (Corning-Costar) culture were made using an inoculum that contained $1 \times 10^{5}$ cells $/ \mathrm{mL}$ (as assayed in a hemacytometer chamber). To each well, $0.1 \mathrm{~mL}$ of the L-929 suspension was added. The plates were incubated at $37{ }^{\circ} \mathrm{C}$ for $18 \mathrm{~h}$ in a humidified incubator with an atmosphere of $5 \% \mathrm{CO}_{2}$ in air. Following the initial incubation, $1.0 \mathrm{mg} / \mathrm{mL}$ of actinomycin D (Sigma) was added into each well, and the plates were incubated at $37^{\circ} \mathrm{C}$ for two $\mathrm{h}$ in a humidified incubator. After this period, we added $0.1 \mathrm{~mL}$ volumes of one of the following: TNF- $\alpha$ standards, samples to be assayed, and control samples. All standards and samples were made in triplicate. The microtiter plates were incubated at $37{ }^{\circ} \mathrm{C}$ for $18 \mathrm{~h}$ in a humidified atmosphere of $5 \%$ $\mathrm{CO}_{2}$ in air. Following the final $18 \mathrm{~h}$ incubation, the remaining adherent (viable) cells were stained for $30 \mathrm{~min}$ at $37^{\circ} \mathrm{C}$ by adding $3 \mu \mathrm{L}$ of MTT (Sigma). The absorbance of each well was measured at $540 \mathrm{~nm}$ using an ELISA plate reader. The serum TNF- $\alpha$ level was calculated through 
a standard curve (recombinant TNF- $\alpha$ cytotoxicity versus cell viability percentage).

7) Hematoxylin-eosin staining: Cell monolayers grown on glass coverslips were infected by $L$. monocytogenes as previously described. The coverslips were washed three times with PBS, fixed with methanol (Merck) for two min, and then hydrated in a graded series of alcohol (Merck) for five min. Subsequently, the coverslips were stained with hematoxylin (Sigma) for 15 - 20 min and then washed with tap water. They were then stained with eosin (Sigma) for $20 \mathrm{~min}$ and washed with distilled water. Finally, the coverslips were dehydrated in a graded series of alcohol, immersed in xylenol (Merck) and mounted in Canada Balsam (Vetec).

8) Electron microscopy: Isolated hepatocytes were pelleted and washed twice in PBS. The resulting pellets were resuspended in $2.5 \%$ glutaraldehyde (Sigma; 0.1 M, pH 7.3) for a minimum of two h at $4{ }^{\circ} \mathrm{C}$. Following fixation, the cells were washed three times in PBS. Cell pellets were post-fixed for two h at $4{ }^{\circ} \mathrm{C}$ in $2 \%$ osmium tetroxide (Sigma) in s-collidine (0.1 M, pH 7.4). Following four PBS rinses, $0.25 \%-0.5 \%$ uranyl acetate (Sigma) was added, and the preparation was allowed to incubate for overnight. After subsequent rinsing with PBS and saline-glucose solution, the pellets were dehydrated in a graded series of alcohol and immersed in acetone (Merck) for five min. Subsequently, the pellets were incubated at $37{ }^{\circ} \mathrm{C}$ for three $\mathrm{h}$ in a solution of Epon Polybed 812/Araldite 502 (Polysciences Inc.) and acetone (1:1). The solution was then removed and the pellets were embedded in Epon Polybed 812 (Polysciences Inc.) and incubated at $65{ }^{\circ} \mathrm{C}$ for $72 \mathrm{~h}$. The preparation was then sectioned. These sections were mounted on copper mesh grids (Sigma) and examined under electron microscopy.

9) TUNEL reaction for detecting apoptosis in situ: We used the TUNEL method described by SGONC et al. ${ }^{26}$ that employ fluoresceindUTP to label DNA strand breaks, with proteinase $\mathrm{K}$ pre-treatment of samples as previously described ${ }^{14}$. Hepatocytes monolayers grown on glass coverslips were infected as previously described ${ }^{14}$. The coverslips were washed three times in PBS and air-dried. Subsequently, the coverslips were fixed for one $\mathrm{h}$ at room temperature in a freshly prepared paraformaldehyde (Sigma) solution (4\% in PBS, pH 7.4). The coverslips were rinsed with PBS and incubated on ice for two min in a permeabilizing solution $n$ of $0.1 \%$ Triton X-100 (Sigma) in $0.1 \%$ sodium citrate (Sigma). The coverslips were then washed with PBS. The area around each sample was dried, and the TUNEL reaction mixture (Boehringer Mannheim) was added. The cells were incubated in a humidified chamber for $30 \mathrm{~min}$ at $37{ }^{\circ} \mathrm{C}$, rinsed three times with PBS, and analyzed under fluorescence microscopy.

10) Statistical analysis: Kruskal-Wallis test and Dunn's post-test were used for statistical analysis. The alpha risk was considered statistically significant when $\leq 5 \%$. The values of TNF- $\alpha$ were expressed as medians and ranging as $25 \%-75 \%$ percentil $^{3}$. All experiments were repeated up to ten times to obtain representative results.

\section{RESULTS}

1) Hepatocytes culture: On the fifth day of primary culture (experimental assay), cell viability was $91.2 \%$, with an average of
$1.8 \times 10^{6}$ hepatocytes $/ \mathrm{mL}$ of medium. The immunohistochemical test was positive for cytokeratins AE1 and AE3. Determination of lactate dehydrogenase $(\mathrm{LDH})$ isoenzymes in the culture supernatants revealed a predominance $(72.2 \%)$ of $\mathrm{LDH}$ fraction 5 , which typically originates in hepatic cells ${ }^{19}$. Albumin was measured in the supernatants in a concentration of $49.8 \mathrm{mg} / \mathrm{L}$. These results confirm hepatocyte primary culture, as well as the morphological analysis performed.

2) Effect of multiplicity of infection on numbers of $\boldsymbol{L}$. monocytogenes recovery from hepatocytes cultures: The effects of L. monocytogenes inoculum size on their ability to invade and multiply in monolayers of hepatocytes were studied by infecting hepatocytes with bacteria at a multiplicity of infection (MOI) of 5:1 (five bacteria to one cell), 50:1, 500:1, 5000:1 and 50,000:1. Bacteria recovered after hepatocyte invasion were expressed as percentage of the original inoculum, and this value was considered an indication of the bacterial invasion degree. When higher MOIs were used, more bacteria were recovered from the monolayers of hepatocytes infected with $L$. monocytogenes.

3) Analysis of TNF- $\alpha$ production by hepatocytes: We found increased quantities of TNF- $\alpha$ released by hepatocytes, dependent on the length of incubation and number of bacteria (Graph 1).

At MOI 5:1, TNF- $\alpha$ release by hepatocytes appeared during the third hour of incubation and peaked during the sixth hour. In the seventh and eighth hours, TNF- $\alpha$ release decreased by approximately $50 \%$. After $24 \mathrm{~h}$ of incubation the TNF- $\alpha$ was undetectable.

At MOI 50:1, TNF- $\alpha$ was detected within the first hour and increased progressively, reaching a peak in the sixth hour. During the seventh and eighth hours, TNF- $\alpha$ release decreased by approximately $20 \%$. After $24 \mathrm{~h}$ of incubation, the quantity of TNF- $\alpha$ released decreased, increasing at $4+24 \mathrm{~h}$ and decreasing again during subsequent hours of incubation.

At MOI 500:1, the quantity of TNF- $\alpha$ released gradually increased from the first hour until the sixth hour of incubation and decreased by approximately $20 \%$ during the seventh and eighth hours. The quantity of TNF- $\alpha$ released decreased an additional $20 \%$ by $4+24 \mathrm{~h}$ of incubation. During subsequent hours, the quantities of TNF- $\alpha$ increased anew.

At MOI 5000:1, the quantity of TNF- $\alpha$ released gradually increased from the first hour until the sixth hour of incubation and decreased by approximately $30 \%$ during the seventh and eighth hours. After $24 \mathrm{~h}$ of incubation, the quantity of TNF- $\alpha$ remained steady. Over the following hours, TNF- $\alpha$ values varied, decreasing at $7+24 \mathrm{~h}$ and at $8+24 \mathrm{~h}$.

At MOI 50,000:1, the quantity of $\mathrm{TNF}-\alpha$ released gradually increased from the first hour until the sixth hour of incubation and decreased by approximately $6 \%$ during the seventh and eighth hours. After $24 \mathrm{~h}$ of incubation, the quantity of TNF- $\alpha$ released decreased $20 \%$. Over the subsequent hours, TNF- $\alpha$ values increased gradually, but decreased at $7+24 \mathrm{~h}$ and at $8+24 \mathrm{~h}$.

Between MOI 5:1 and MOI 50:1, there were significant differences in the levels of TNF- $\alpha$ released at the various incubation times. 


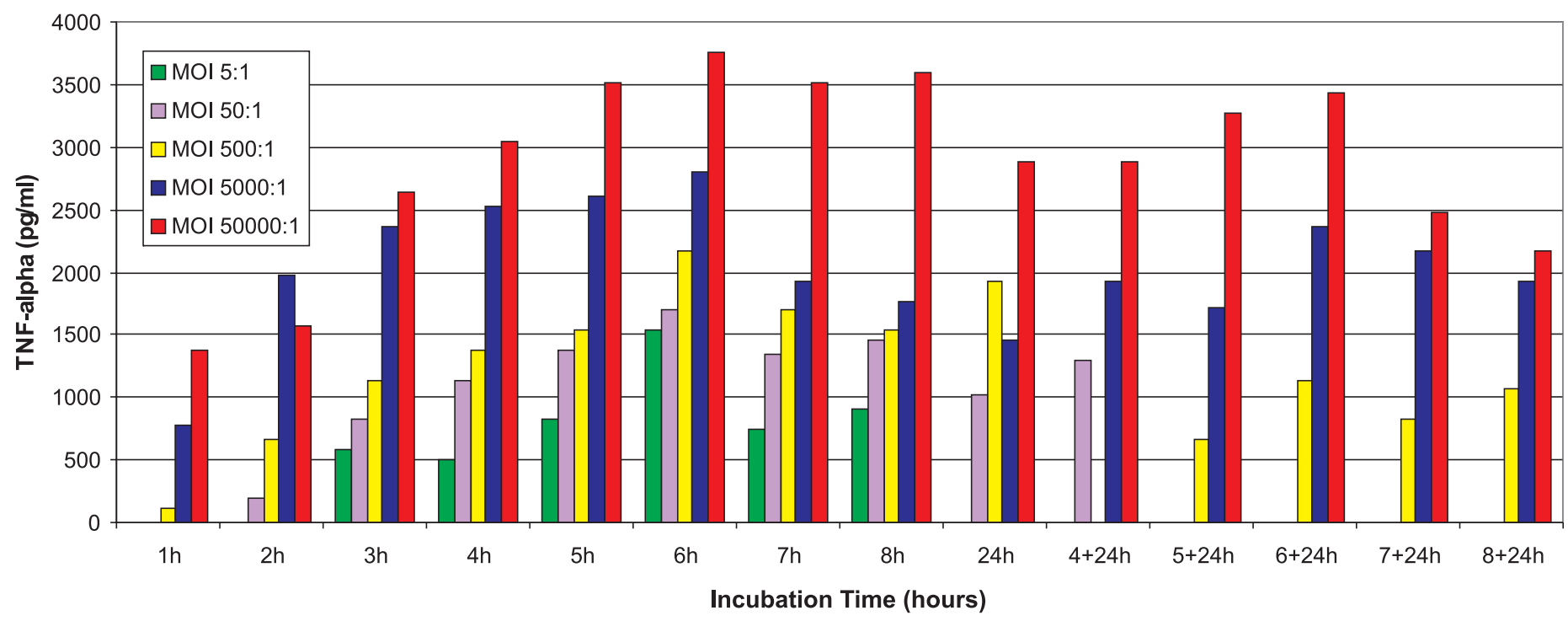

Graph 1. Time-dependent progressive production of TNF- $\alpha$ by rat hepatocytes in a primary culture invaded by Listeria monocytogenes

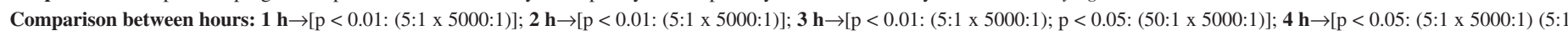

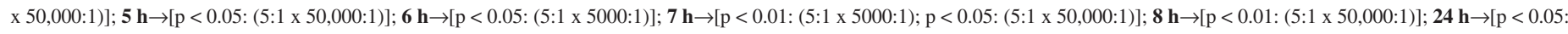

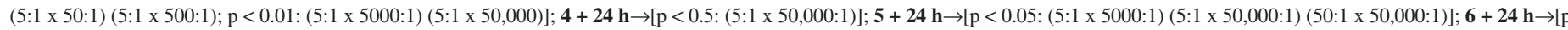

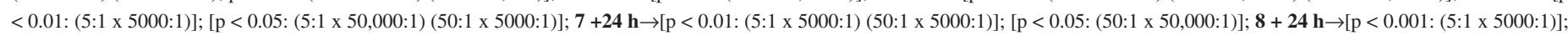
[p < 0.01: (5:1 x 50,000:1)]; [p <0.05: (5:1 x 500:1) (50:1 x 5000:1)].

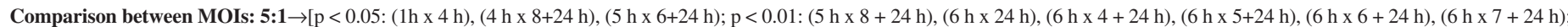

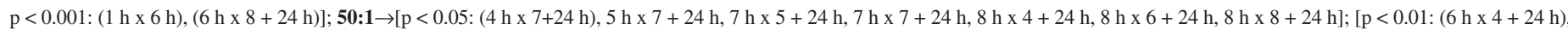
$(6 \mathrm{~h} \times 5+24 \mathrm{~h}),(6 \mathrm{~h} \times 6+24 \mathrm{~h}),(6 \mathrm{~h} \times 8+24 \mathrm{~h}),(8 \mathrm{~h} \times 5+24 \mathrm{~h}),(8 \mathrm{~h} \times 7+24 \mathrm{~h})] ; \mathrm{p}<0.001: 6 \mathrm{~h} \times 7+24 \mathrm{~h} ; \mathbf{5 0 , 0 0 0 : 1} \rightarrow \mathrm{p}<0.05: 1 \mathrm{~h} \times 8 \mathrm{~h}$.

However, among MOIs 500:1, 5000:1 and 50,000:1 there were no significant differences in the levels of TNF- $\alpha$ released at the various incubation times. At very high MOIs, hepatocytes appeared to reach maximal TNF- $\alpha$ release, producing similar quantities of TNF- $\alpha$ at the various incubation times.

The statistical analysis shows significant differences between TNF- $\alpha$ released values at MOI 5:1. At other MOIs, no statistically significant differences were found between quantities of TNF- $\alpha$ released at the various incubation times (Graph 1). In the comparison among different MOIs and their incubation times we verify that there was significant difference between the following groups: MOIs 5:1 and 5000:1 in the first hour, second hour, third hour, fourth hour, sixth hour and seventh hour; MOIs 50:1 and 5000:1 in the third hour; MOIs 5:1 and 50,000:1 in the fourth hour, fifth hour, seventh hour and eighth hour. At $24 \mathrm{~h}$ of incubation there were significant differences between MOIs 5:1 and 50:1, MOIs 5:1 and 500:1, MOIs 5:1 and 5000:1 and MOIs 5:1 and $50,000: 1$. In the groups of composite hours there were significant differences between groups: MOIs 5:1 and 5000:1 in the $5+24 \mathrm{~h}, 6+$ $24 \mathrm{~h}, 7+24 \mathrm{~h}$ and $8+24 \mathrm{~h}$; MOIs 5:1 and 50,000:1 in the $4+24 \mathrm{~h}, 5$ $+24 \mathrm{~h}, 6+24 \mathrm{~h}$ and $8+24 \mathrm{~h}$; MOIs 50:1 and 50,000:1 in the $5+24 \mathrm{~h}$ and $7+24 \mathrm{~h}$; MOIs 50:1 and 5000:1 in the $6+24 \mathrm{~h}, 7+24 \mathrm{~h}$ and $8+$ $24 \mathrm{~h}$; MOIs 5:1 and 500:1 in the $8+24 \mathrm{~h}$.

4) Detection of apoptosis: Apoptosis was detected by TUNEL technique in hepatocytes cultures with $5 \times 10^{6}$ bacteria (MOI 5:1), beginning in the third hour of infection and increasing until the eighth hour. By $24 \mathrm{~h}$, apoptosis had decreased by $8 \%$. After $4+24 \mathrm{~h}$ and until $8+24 \mathrm{~h}$, apoptosis levels increased. At MOI 50:1, apoptosis began within the first hour of incubation, increasing until the eighth hour, decreasing $(7 \%)$ by $24 \mathrm{~h}$, and increasing again over the following hours (from $4+24$ h until $8+24$ h; Graph 2).

5) Microscopic analysis of infected cells: After infection with $L$. monocytogenes, hepatocytes were analyzed under light microscopy in order to evaluate the ability of the invasive bacteria to induce cytopathic effects.

Hematoxylin-eosin-stained preparations of hepatocytes infected with L. monocytogenes at a MOI of 5:1 showed no disruption of the cell monolayers and no cytopathic changes. The morphology of these cells was similar to that of uninfected cells. Hepatocyte cell monolayers retained confluence, without loss of viability as seen in control cell monolayers. At a MOI of 50,000:1, cell monolayers of hepatocytes infected with L. monocytogenes showed a marked loss of confluence, and viable cells were heavily infected with bacteria.

Hepatocytes cultured at MOI 5:1, under optical microscopy, have suffered structural modifications beginning in the third hour of incubation with L. monocytogenes. At MOI 50:1, such modifications began in the second hour of incubation. It has been established that microscopically detectable dynamic morphological changes induced by bacteria always occur within the first two hours of incubation ${ }^{17,18}$.

Cell fragments increased from the fourth hour of incubation at MOIs 5:1 and 50:1. Just at MOI 50:1, the number of cell fragments began to increase in the sixth hour of incubation (Table 1). At $7+24 \mathrm{~h}$ of incubation at MOI 50:1, hepatocytes monolayers became disorganized, and vacuolization of the cytoplasm occurred. 


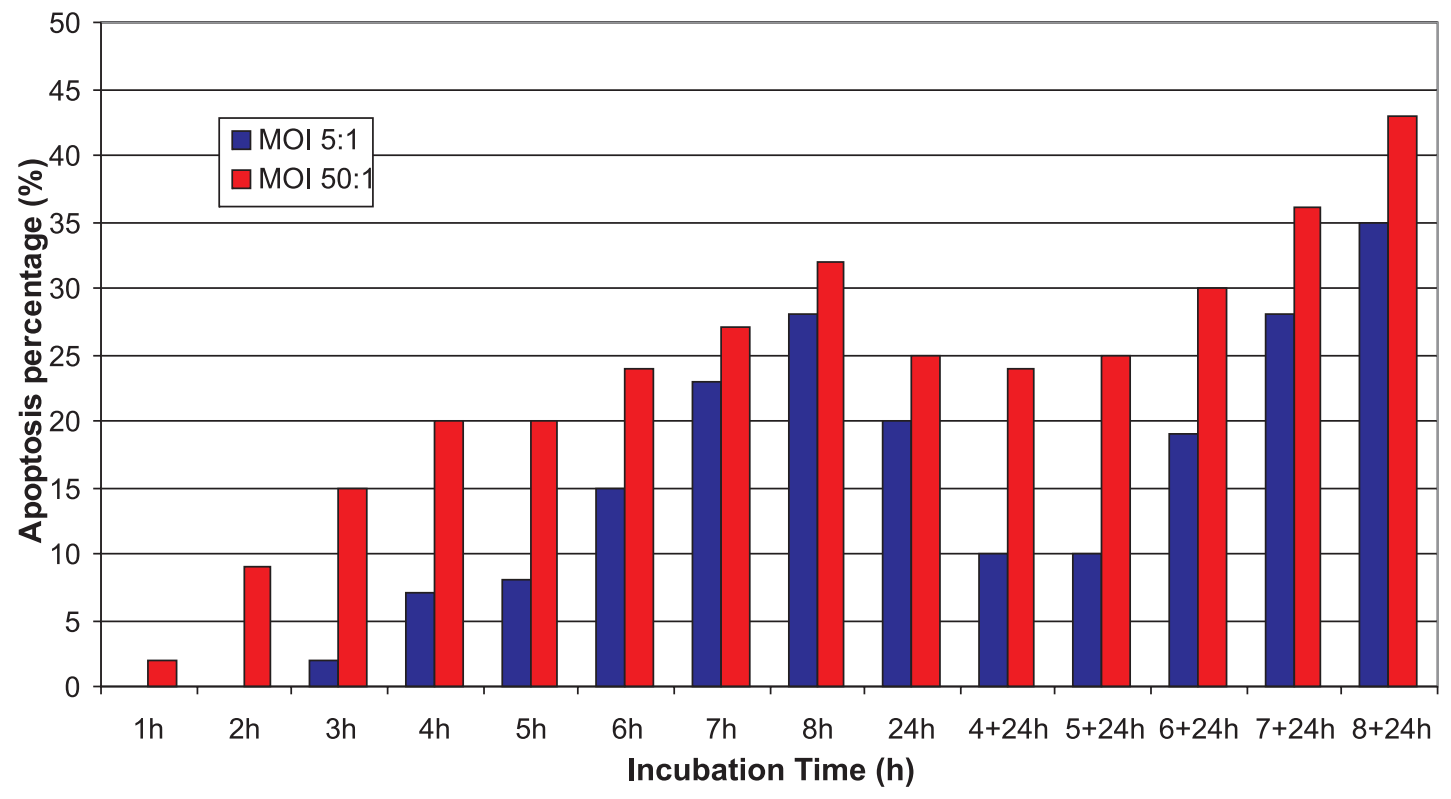

Graph 2. Apoptosis percentage of rat hepatocytes invaded by Listeria monocytogenes. MOI 5:1= $5 \times 10^{6}$ bacteria: $1 \times 10^{6}$ hepatocytes; MOI $50: 1=5 \times 10^{7}$ bacteria: $1 \times 10^{6}$ hepatocytes.

Table 1

Hepatocytes morphological characteristics invaded by Listeria monocytogenes at MOIs 5:1 and 50:1

\begin{tabular}{lccc}
\hline Incubation Time & Control & MOI 5:1 & MOI 50:1 \\
\hline $\mathbf{1 h}$ & $\mathrm{N}$ & $\mathrm{N}$ & $\mathrm{N}$ \\
$\mathbf{2 h}$ & $\mathrm{N}$ & $\mathrm{N}$ & $\mathrm{A}$ \\
$\mathbf{3 h}$ & $\mathrm{N}$ & $\mathrm{A}$ & $\mathrm{A}$ \\
$\mathbf{4 h}$ & $\mathrm{N}$ & $\mathrm{AF}$ & $\mathrm{AF}$ \\
$\mathbf{5 h}$ & $\mathrm{N}$ & $\mathrm{AF}$ & $\mathrm{AF}$ \\
$\mathbf{6 h}$ & $\mathrm{N}$ & $\mathrm{AF}$ & $\mathrm{AMF}$ \\
$\mathbf{7 h}$ & $\mathrm{N}$ & $\mathrm{AF}$ & $\mathrm{AMF}$ \\
$\mathbf{8 h}$ & $\mathrm{N}$ & $\mathrm{AF}$ & $\mathrm{AMF}$ \\
$\mathbf{2 4 h}$ & $\mathrm{N}$ & $\mathrm{AF}$ & $\mathrm{AMF}$ \\
$\mathbf{4 + 2 4 h}$ & $\mathrm{N}$ & $\mathrm{AF}$ & $\mathrm{AMF}$ \\
$\mathbf{5 + 2 4 h}$ & $\mathrm{N}$ & $\mathrm{AF}$ & $\mathrm{AMF}$ \\
$\mathbf{6 + 2 4 h}$ & $\mathrm{N}$ & $\mathrm{AF}$ & $\mathrm{AMF}$ \\
$\mathbf{7 + 2 4 h}$ & $\mathrm{N}$ & $\mathrm{AF}$ & $\mathrm{AMF}$ \\
$\mathbf{8 + 2 4 h}$ & $\mathrm{N}$ & $\mathrm{AF}$ & $\mathrm{AMF}$ \\
\hline
\end{tabular}

Note: $\mathrm{N}=$ normal cell; $\mathrm{A}=$ cell with morphological modifications (membrane, shape); $\mathrm{F}=$ cell fragments; $\mathrm{MF}=$ several cell fragments.

Apoptosis was determined by both light and electron microscopy and was defined as cells exhibiting any of the following morphological features: a) the formation of sharply-delineated, uniform, fine granular masses or crescents, b) nuclear fragments, c) condensed cytoplasm, d) apoptotic bodies, e) phagocytosis of apoptotic cells by adjacent cells. Morphologically, under electron microscopy, apoptotic cells presented nuclear chromatin condensation, compact cytoplasmic organelles, and pedunculated protuberances on the cell surface (Fig. 2). Hepatocytes presented dilation of the endoplasmic reticulum. Apoptotic nuclei, characterized by chromatin condensation, were found sparsely distributed in hepatocytes. Apoptotic fragments and apoptotic bodies were frequently observed. Apoptotic cell duration is limited to only a few minutes ${ }^{13,16,24,25}$, and apoptotic bodies in diverse forms are seen for only a few hours before they are phagocyted ${ }^{6,29}$.

\section{DISCUSSION}

Listeria monocytogenes strain used in our experiments was nonhemolytic. Hemolytic and non-hemolytic L. monocytogenes strains exhibit similar abilities to invade hepatocytes, but only hemolytic $L$. monocytogenes multiply within this cell line ${ }^{28}$. It was used $1 \mu \mathrm{g}$ of gentamicin per $\mathrm{mL}$ to inhibit the growth of extracellular bacteria. Preliminary data demonstrated that this concentration of gentamicin inhibited extracellular multiplication of the Listeria while allowing an approximately 100-fold increase in intracellular L. monocytogenes to occur in a $24 \mathrm{~h}$ incubation period ${ }^{28}$. In our later groups the results probably reflect the fact that gentamicin was not totally excluded from cells in vitro. The high extracellular gentamicin concentration might be inhibitory to L. monocytogenes multiplication in the hepatocyte cytoplasm $^{28}$.

Hepatocytes can play an important role in the initiation and amplification of the acute inflammatory response in the liver. There are some pathways by which the pro-inflammatory cytokine production in hepatocytes could be activated. In one of those, hepatocytes cytokine production would be stimulated by agonists secreted by Küpffer cells or other cells in the liver, such as endothelial cells, which are situated in close proximity to hepatocytes ${ }^{23}$.

The hepatocyte is a major site of L. monocytogenes replication in liver, in comparison with Küpffer cells. Therefore, this cell is the best choice as a target to intracellular bacteria ${ }^{7,12,22}$.

We performed the bioassay method to quantify TNF- $\alpha$. Other 
methods like antibody based assays such as RIAs and ELISAs detect both active and inactive TNF, and they may not accurately measure true biological TNF activity. In vitro bioassays may provide a rapid and sensitive means for the detection and quantification of various cytokines. Other cytokines, including IL- $1 \alpha$, IFN- $\gamma$ and TGF- $\beta$, do not interfere with the accurate determination of the TNF levels ${ }^{4}$, and it is not necessary to block these cytokines during bioassay to determine TNF- $\alpha$. This methodology presented statistical specificity and sensibility.

We verify that the TNF- $\alpha$ levels in the supernatants increased from the $1^{\text {st }} \mathrm{h}$ of incubation (hepatocytes + bacteria) until the $6^{\text {th }} \mathrm{h}$ of incubation. At $7^{\text {th }}$ and $8^{\text {th }} \mathrm{h}$ of incubation there was a decrease, non significant, of TNF- $\alpha$ levels. We speculate that this phenomenon could be related to stability of TNF- $\alpha$. Until $6^{\text {th }} \mathrm{h}$ of incubation, the TNF- $\alpha$ values were ascendants, but at $7^{\text {th }} \mathrm{h}$ there was decrease of 30 to $50 \%$. The stability of TNF- $\alpha$ depends on the store temperature being total at $-70{ }^{\circ} \mathrm{C}{ }^{4}$. It's possible that the temperature used in the assays $\left(37^{\circ} \mathrm{C}\right)$ has contributed to decrease of TNF- $\alpha$ biological activity mainly from $7^{\text {th }} \mathrm{h}$ of incubation. Other possibilities to justify the decrease of the values of TNF- $\alpha$ at $7^{\text {th }}$ and $8^{\text {th }} \mathrm{h}$ would be the saturation of cellular receptors or activation of NF-kB from $6^{\text {th }} \mathrm{h}$ of incubation, decreasing the TNF- $\alpha$ released by hepatocytes.

We also observed that at $24^{\text {th }} \mathrm{h}$ of incubation the TNF- $\alpha$ values increased, but were smaller than that verified at $6^{\text {th }} \mathrm{h}$ of incubation. We speculate that the time of incubation superior may explain the increase in the TNF- $\alpha$ production by cells incubated during $24 \mathrm{~h}$, in spite of saturation of receptors. In the composite hours with addition of gentamicin to eliminate extracellular microorganisms, there were increased levels of TNF- $\alpha$, although smaller that those observed at the first $6 \mathrm{~h}$ of incubation. In the composite times of incubation with gentamicin, we intended investigate if the internalized bacteria would be able to induce the production of TNF- $\alpha$ and/or apoptosis. Our results showed that the aggression by bacterial invasion, alone, was capable to induce the release of TNF- $\alpha$ and unleash the death of hepatocytes by apoptosis.

When we increased progressively the MOI (multiplicity of infection), we verified that the differences between TNF- $\alpha$ levels between $1^{\text {st }} \mathrm{h}$ to $8^{\text {th }} \mathrm{h}$ of incubation decreased in a time-dependent form. The difference among TNF- $\alpha$ released in every hour of incubation was non-significant. At MOI 5:1 and 50:1 there were significant differences between the levels of TNF- $\alpha$ released in the several times of incubation. At MOI 500:1, 5000:1 and 50,000:1 there were not significant differences in the levels of TNF- $\alpha$ released in the several periods of incubation. We speculate that at very high MOI, the hepatocytes seem to reach the maximal capacity to release $\mathrm{TNF}-\alpha$, producing similar values in different times of incubation. This phenomenon may be explained as likely saturation of receptors of the host cell invaded or saturation of cell signaling pathways.

The TNF- $\alpha$ levels in the supernatants of invaded hepatocytes indicate that these cells are susceptible to aggression by L. monocytogenes. This bacterium probably developed adaptability to hepatocytes because it can meet these cells too easy in the environment. Although low levels of TNF- $\alpha$ were seen in the first hours of invasion (MOI 5:1 and 50:1), Listeria monocytogenes was found inside hepatocytes since the first hour of incubation (Fig. 1), and the cellular death by apoptosis already occurred in this period. This phenomenon shows the great capacity of the cell destruction by L. monocytogenes. These results are different of that found for Salmonella typhimurium that apparently invades hepatocytes only in the $3^{\text {rd }} \mathrm{h}$ of incubation ${ }^{1}$.

In the comparison among MOIs in each incubation time, we observed that the release of TNF- $\alpha$ increases with the bacteria:cell rate (Graph 1). This tendency was confirmed in the comparison among incubation times within each MOI. Both tests indicate that the release of TNF- $\alpha$ increase with the time of incubation, as well as bacteria:cell rate (MOI).

In the morphological analysis by optical microscopy, the hepatocytes cultivated with $L$. monocytogenes at MOI 5:1, suffered structural modifications from the $3^{\text {rd }} \mathrm{h}$ of incubation. At MOI 50:1 the cell modifications started in the $2^{\text {nd }} \mathrm{h}$ of incubation. Other researchers $\mathrm{s}^{17,18}$ showed that dynamic morphological changes always occur in at least two hours of incubation with bacteria.

The cellular fragments arose from the $4^{\text {th }} \mathrm{h}$ of incubation in both MOIs (5:1 and 50:1). At MOI 50:1, the number of fragments increased from the $6^{\text {th }} \mathrm{h}$ of incubation. There was disorder of hepatocytes monolayers in $7+24 \mathrm{~h}$ of incubation, and vacuolization of cytoplasm at MOI 50:1.

Listeria monocytogenes strain used in this work was non-hemolytic, and it was found inside the hepatocyte in the $1^{\text {st }} \mathrm{h}$ of incubation. This result proves that the non-hemolytic strain presents efficient process of internalization. WOOD et al. ${ }^{28}$, also showed that non-hemolytic character of L. monocytogenes do not affect the invasive ability.

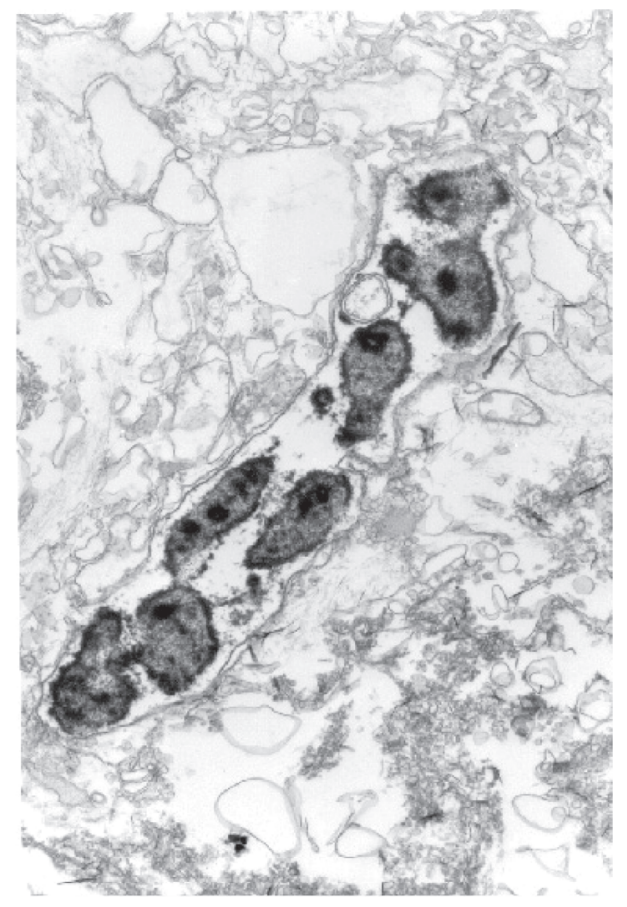

Fig. 1 - Micrograph of hepatocyte invaded by Listeria monocytogenes; MOI 5:1/1 h of incubation. (x12,000, EM). 


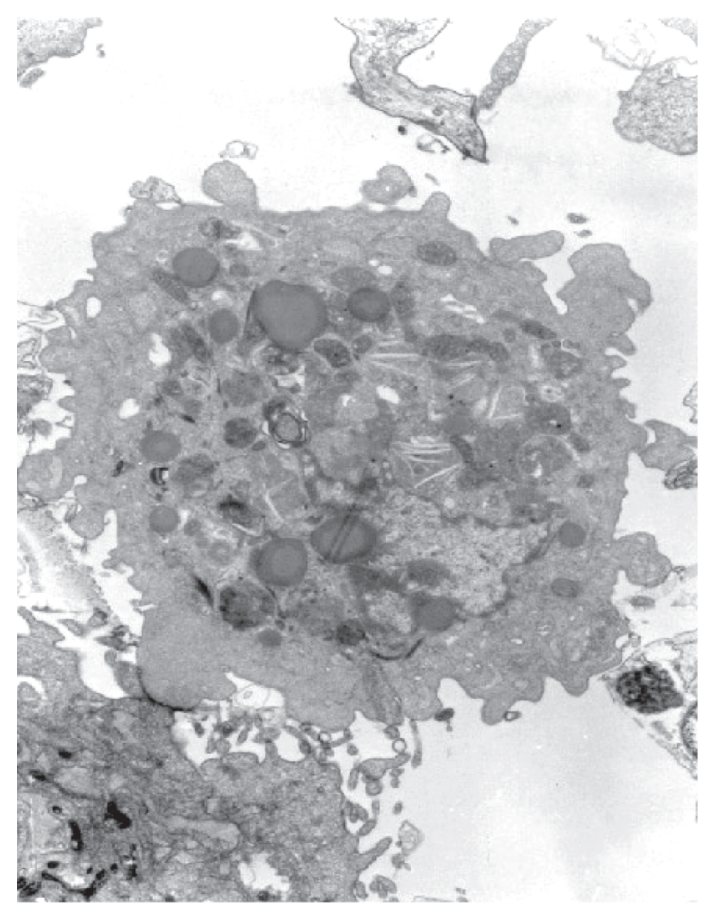

Fig. 2 - Micrograph of apoptotic hepatocyte invaded by Listeria monocytogenes; MOI 5:1/4 + $24 \mathrm{~h}$ of incubation (x 5,000, EM).

Our results show that the frequency of apoptosis increased directly with the time of incubation. At $7^{\text {th }}$ and $8^{\text {th }} \mathrm{h}$ of incubation, despite low levels of TNF- $\alpha$, there was also increase of apoptosis. In some studies ${ }^{5,18}$ was verified that the point of no return of apoptosis occur several hours before the appearance of morphologic features. The apoptosis that occur from the $7^{\text {th }}$ and $8^{\text {th }} \mathrm{h}$ of incubation might be independent of concomitant TNF- $\alpha$ release. This phenomenon was observed by others ${ }^{8}$, when hepatocytes infected by L. monocytogenes dead by apoptosis, even after neutralization of TNF- $\alpha$, IL-1, IL-6, IL-12 and IFN- $\gamma$, cytokines that stimulate apoptosis under certain conditions. We speculate that Listeria monocytogenes is a necessary stimulus to induction of apoptosis, possibly through stimulation by the bacteria products.

The hepatocytes invaded by non-hemolytic L. monocytogenes released TNF- $\alpha$ in increased quantities, until their receptors were partially saturated, probably from the $7^{\text {th }} \mathrm{h}$ of incubation. We observed that incubation of hepatocytes monolayers with bacterial suspensions in increasing concentrations (MOI) resulted in the similar TNF- $\alpha$ production in different times of incubation. The phenomenon of saturation of receptors may explain this question. Apoptosis rate, seems to increase with the time of incubation and the MOI (multiplicity of infection), being TNF- $\alpha$ the indispensable factor to this process, until that its presence be unnecessary to the permanence of the phenomenon.

Our work intended to help in the knowledge of the interaction between invasive bacteria and its target-cell, as well as the complex phenomena that are initiated after this meeting. The production of a pro-inflammatory cytokine, like TNF- $\alpha$, by the hepatocytes and the induction of apoptosis show that an epithelial cell when infected by bacteria may be surprising. The dimension of this phenomenon is unclear. We believe that the future of infectious diseases combat must be centralized in the knowledge of infectious agent versus host cells fighting.

\section{RESUMO}

\section{Invasão de hepatócitos de rato por Listeria monocytogenes e análise do papel do TNF- $\alpha$ na apoptose}

Listeria monocytogenes, agente etiológico de infecção grave de origem alimentar, utiliza mecanismos sofisticados de entrada no citoplasma do hospedeiro e manipulação do citoesqueleto, resultando em morte celular. As interações entre células do hospedeiro e bactérias podem resultar em produção de citocinas como o Fator de Necrose Tumoral alfa (TNF- $\alpha)$. Hepatócitos têm potencial de produzir citocinas pro-inflamatórias como TNF- $\alpha$, quando invadidos por bactérias. No presente trabalho demonstramos o comportamento dos hepatócitos invadidos por L. monocytogenes pela análise microscópica, determinação da produção de TNF- $\alpha$ por bioensaio e análise da apoptose pela técnica TUNEL. A presença da bactéria, na razão que variou de 5 a 50.000 bactérias por célula, induziu ruptura das monocamadas celulares. Observamos presença de bactérias internalizadas na $1^{\mathrm{a}}$ hora de incubação por microscopia eletrônica. Os níveis de TNF- $\alpha$ aumentaram da $1^{\text {a }}$ hora de incubação até a $6^{\text {a }}$ hora, variando de 0 a $3749 \mathrm{pg} / \mathrm{mL}$. Nas $7^{\mathrm{a}}$ e $8^{\mathrm{a}}$ horas de incubação, ocorreram quedas não significativas dos níveis de TNF- $\alpha$, indicando possível saturação dos receptores celulares. A quantidade de TNF- $\alpha$ produzido por hepatócitos foi dependente do tempo de incubação, assim como da proporção entre bactérias e células. A taxa de apoptose aumentou diretamente com o tempo de incubação $(1 \mathrm{~h} \mathrm{a} 8+24 \mathrm{~h}$ ), variando de 0 a $43 \%$, assim como com a razão bactérias : células. Estes resultados mostram a habilidade de L. monocytogenes não-hemolítica em invadir os hepatócitos, e as principais conseqüências deste fenômeno são: liberação de TNF- $\alpha$ e indução de apoptose. Assim, podemos especular que hepatócitos usam apoptose induzida por TNF- $\alpha$ para liberar bactérias de seu interior, facilitando a destruição destas pelo sistema imune.

\section{ACKNOWLEDGEMENTS}

This work was supported by grants from Fundação de Amparo à Pesquisa do Estado de São Paulo (FAPESP).

\section{REFERENCES}

1. ANDRADE, D.R.; ANDRADE JÚNIOR, D.R.; ORI, M. \& SANTOS, S.A. - Invasion of rat hepatocytes in a primary culture by Salmonella typhimurium: production of TNF alpha and analysis of the cell death. Hepatology, 30(suppl. 4, part 2): 546A, 1999.

2. ANDRADE JÚNIOR, D.R. - Estudo de hepatócitos de rato em cultura primária "in vitro" submetidos à hipóxia: análise da lesão celular e do papel citoprotetor da prostaglandina E1. São Paulo, 1992. (Dissertação de Mestrado - Faculdade de Medicina da Universidade de São Paulo).

3. ANDRADE JÚNIOR, D.R.- Estudo de hepatócitos de rato em cultura primária submetidos a hipóxia e reoxigenação: ação dos citoprotetores prostaglandina E1, superóxido dismutase, verapamil, alopurinol, clorpromazina, e efeito citotóxico da actinomicina D. São Paulo, 1996. (Tese de Doutoramento - Faculdade de Medicina da Universidade de São Paulo).

4. BRANCH, D.R.; SHAH, A. \& GUILBERT, L.J. - A specific and reliable bioassay for the detection of fentomolar levels of human and murine tumor necrosis factors. $\mathbf{J}$. immunol. Meth., 143: 251-261, 1991. 

47(2):73-80, 2005.

5. BRUNET, C.L; GUNBY, R.H.; BENSON, R.S et al. - Commitment to cell death measured by loss of clonogenicity is separable from the appearance of apoptotic markers. Cell Death Differ., 5: 107-115, 1998

6. BRUSCH, W.; KLEINE, L. \& TENNISWOOD, M. - The biochemistry of cell death by apoptosis. Biochem. Cell Biol., 68: 1071-1074, 1990.

7. CONLAN, J.W. \& NORTH, R.J. - Neutrophil-mediated dissolution of infected host cells as a defense strategy against a facultative intracellular bacterium. J. exp. Med., 174: 741-744, 1991.

8. COUSENS, L.P. \& WING, E.J. - Innate defenses in the liver during Listeria infection. Immunol. Rev., 174: 150-159, 2000.

9. FARBER, J.M. \& SPEIRS, J.I. - Potential use of continuous cell lines to distinguish between pathogenic and nonpathogenic Listeria spp. J. clin. Microbiol., 25: 14631466, 1987.

10. FIERS, W. - Tumor necrosis factor. Characterization at the molecular, cellular and in vivo level. FEBS Lett., 285: 199-212, 1991

11. GEDDE, M.M.; HIGGINS, D.E.; TILNEY, L.G. \& PORTNOY, D.A. - Role of listeriolysin $\mathrm{O}$ in cell-to-cell spread of Listeria monocytogenes. Infect. Immun., 68: 999-1003, 2000 .

12. HAVELL, E.A. \& SEHGAL, P.B. - Tumor necrosis factor-independent IL-6 production during murine listeriosis. J. Immunol., 146: 756-761, 1991.

13. KERR, J.F.R.; WYLLIE, A.H. \& CURRIE, A.R. - Apoptosis: a basic biological phenomenon with wide-ranging implications in tissue kinetics. Brit. J. Cancer, 26: 239-257, 1972

14. LABAT-MOLEUR, F.; GUILLERMET, C.; LORIMIER, P. et al. - TUNEL apoptotic cell detection in tissue sections: critical evaluation and improvement. J. Histochem. Cytochem., 46: 327-334, 1998.

15. LORBER, B. - Listeriosis. Clin. infect. Dis., 24: 1-11, 1997.

16. MATTER, A. - Microcinematographic and electron microscopic analysis of target cells lysis induced by cytotoxic T lymphocytes. Immunology, 36: 179-190, 1979.

17. McCARTHY, N.J.; WHYTE, M.K.B.; GILBERT, C.S. \& EVAN, G.I. - Inhibition of Ced-3/ICE-related proteases does not prevent cell death induced by oncogenes, DNA damage, or the Bcl-2 homologue Bak. J. Cell Biol., 136: 215-227, 1997.

18. MESSAM, C.A. \& PITTMAN, R.N. - Asynchrony and commitment to die during apoptosis. Exp. Cell Res., 238: 389-398, 1998.
19. MOURA, R.A.A.; PURCHIO, A.; ROSSI, A.L.R. et al. - Técnicas de laboratório. 2. ed. Rio de Janeiro, Atheneu, 1982. p. 239-251

20. REMER, K.A.; JUNGI, T.W.; FATZER, R.; TAUBER, M.G. \& LEIB, S.L. - Nitric oxide is protective in listeric meningoencephalitis of rats. Infect. Immun., 69: 4086-4093, 2001

21. ROGERS, H.W.; CALLERY, M.P.; DECK, B. \& UNANUE, E.R. - Listeria monocytogenes induces apoptosis in infected hepatocytes. J. Immunol., 156: 679-684, 1996.

22. ROSEN, H.; GORDON, S. \& NORTH, R.J. - Exacerbation of murine listeriosis by a monoclonal antibody specific for the type 3 complement receptor of myelomonocytic cells. Absence of monocytes at infective foci allows Listeria to multiply in nonphagocytic cells. J. exp. Med., 170: 27-37, 1989.

23. ROWELL, D.L.; ECKMANN, L.; DWINELL, M.B. et al. - Human hepatocytes express an array of pro-inflammatory cytokines after agonist stimulation of bacterial invasion. Amer. J. Physiol. Gastroint. Liver Physiol., 273: G322-G332, 1997.

24. RUSSEL, S.W.; ROSENAU, W. \& LEE, J.C. - Cytolysis induced by human lymphotoxin Amer. J. Path., 69: 103-118, 1972.

25. SANDERSON, C.J. - The mechanism of T cell mediated cytotoxicity. II. Morphological studies of cell death by time-lapse microcinematography. Proc. roy. Soc. Lond. B., 192: 241-255, 1976.

26. SGONC, R.; BOECK, G.; DIETRICH, H. et al. - Simultaneous determination of cell surface antigens and apoptosis. Trends Genet., 10: 41-42, 1994.

27. UTERMÖHLEN, O.; KAROW, U.; LÖHLER, J. \& KRONKE, M. - Severe impairmen in early host defense against Listeria monocytogenes in mice deficient in acid sphingomyelinase. J. Immunol., 170: 2621-2628, 2003.

28. WOOD, S.; MAROUSHEK, N. \& CZUPRYNSKI, C.J. - Multiplication of Listeria monocytogenes in a murine hepatocyte cell line. Infect. Immun., 61: 3068-3072, 1993.

29. WYLLIE, A.H. - Glucocorticoid-induced thymocyte apoptosis is associated with endogenous endonuclease activation. Nature (Lond.), 284: 555-556, 1980.

30. YIN, X.M. \& DING, W.X. - Death receptor activation-induced hepatocyte apoptosis and liver injury. Curr. mol. Med., 3: 491-508, 2003.

31. ZHENG, S.J.; WANG, P.; TSABARY, G. \& CHEN, Y.N. - Critical roles of TRAIL in hepatic cell death and hepatic inflammation. J. clin. Invest., 113: 58-64, 2004

Received: 11 November 2004

Accepted: 22 February 2005 